\title{
Assessment of Soil Erosion in Siruvani Watersheds Based on USLE and Hypsometric Curve Methods
}

\author{
A.Tamilarasan, J. Brema
}

\begin{abstract}
Soil erosion poses a serious threat over the maintenance activities of a reservoir and its watershed. This study has been taken us to assess the extent of soil erosion in the watersheds of the Siruvani Reservoir located in the district of Kerala. Two methods namely, Universal Soil Loss equation (USLE) and Hypsometric curve methods are adapted in this study. Hypsometry of watersheds (area-elevation analysis) has generally been used to reveal the stages of geomorphic development (stabilized, mature and young). The watersheds of Siruvani Reservoir were delineated from the generated Digital Elevation Model (DEM) using Geographic Information System (GIS). Various set of data like land use map, rainfall and soil map have been used for this analysis to generate five factors namely finally, the soil erosion risk map was created to identify the regions which are susceptible to erosion. Hypsometric analysis deals with measurement of the interrelationships between basin area and altitude of basin which has been used to understand the influence of various factors such as climate, geology and tectonic changes. GIS provides advanced tools to obtain hypsometric information and also helps to estimate the associated parameters of landforms. The entire study area has been sub-divided into 5 watersheds for hypsometric analysis and their area ranges from 1.77 to $6.94 \mathrm{~km} 2$. The hypsometric curve of the whole the watersheds reflects the mature geomorphic terrain whereas hypsometric integral indicates that the drainage basin has already eroded per cent of land masses. These findings would emphasize the importance of soil and water conservation measures to be taken up in the Siruvani watersheds for controlling further erosion, reducing the sediment outflows and conserve water.
\end{abstract}

Keywords - watershed, factors, erosion, hypsometry

\section{INTRODUCTION}

In this study, the focus is to find the soil erosion by using USLE (universal soil loss equation) and Hypsometric curve in the Siruvani reservoir. Universal soil loss equation is used for the soil loss determination in the study area. The USLE is a worldwide equation used for soil loss and it estimates long term average annual gross soil erosion. Hypsometric curve is a type of graph which show the proportion of surface area of earth at various elevation by plotting relative area against relative height. This will be used to assess the evolutionary condition of the landform forms; it is related to the volume of the soil mass in the basin and the amount of erosion that had occurred in a basin against the remaining mass. The study is carried out for each of these watersheds using this equation

Revised Manuscript Received on April 12, 2019.

A.Tamilarasan, Student, Department of Civil Engineering, Karunya Institute of Technology and Sciences, Coimbatore, T.N, India.

J. Brema, Professor, Department of Civil Engineering, Karunya Institute of Technology and Sciences, Coimbatore, T.N, India.

\section{LITERATURE REVIEW}

J. W. MA et al, (2003) carried out a study in the Minjiang River Valley, one of the largest river valleys in the Upper Yangtze River watershed. Because of Its large size, it is very difficult to calculate the amount of soil losses for the valley when a traditional sample method was used to collect the data for the Universal Soil Loss Equation (USLE model). The values of parameters extracted from satellite sensor data for soil erosion USLE model calculation was based on pixels. In this way, it improves the accuracy for every parameter calculation. P. P. Dabral et al, (2008) have done soil erosion assessment in Dikrong river basin of Arunachal Pradesh by dividing the study area into $200 \times 200 \mathrm{~m}$ grid cell. Fistikoglu et al, (2002) have integrated both Geographic Information System (GIS) and the USLE (Universal Soil Loss Equation) model to identify rainfall-based erosion. The study was carried to identify the gross erosion, sediment loads, and organic $\mathrm{N}$ loads within a small region of the Gediz River basin. J.V.Perez-Pena et al,(2009) have presented a new ArcGIS extension known as CalHypso which is used to extract hypsometric curve from Digital Elevation model. Sagy Cohen et al, (2008) have created a quantitative representation of the area-slope equation and the hypsometric integral to apply in various applications of geomorphology. Fuzal Ahmed et al, (2016) have subdivided their study area into 22sub-basins to form Hypsometric curve. The hypsometric differentiates the erosional landform and evolution of different stages.

\section{STUDY AREA}

Siruvani reservoir is situated in Palakkad district, Kerala $46 \mathrm{~km}$ away from Palakkad. This reservoir constructed across the Siruvani river, is enabling drinking water supply to the city of Coimbatore, Tamil Nadu. The reservoir is surrounded by reserve forests. Muthikulam hill is situated on the eastern side of the dam with natural waterfalls. An agreement was executed in August 1973 between the state Governments for drinking water supply to Coimbatore town and neighboring areas from the Siruvani reservoir to construct dam. The location being in the state of Kerala, the project was executed by the Kerala Public Works Department using the funds made available by the Tamil Nadu Government. The reservoir has an area of $21 \mathrm{~km}^{2}$ and has a perimeter of $1.52 \mathrm{~km}$. 


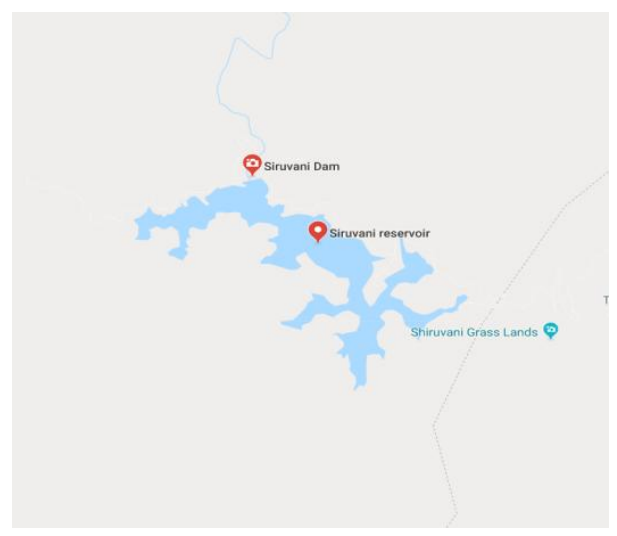

Fig.1. Siruvani Reservoir

\section{REMOTE SENSING DATA}

The Digital Elevation Model is downloaded from USGS Earth Explorer. In this present study, the DEM used is SRTM with a resolution of $90 \mathrm{~m}$. SRTM Non-Void elevation data was processed from raw C-band radar signals spaced at intervals of 1 arc-second at NASA's Jet Propulsion Laboratory (JPL). Fig.2 shows the downloaded SRTM data extracted with the help of watershed shapefile.

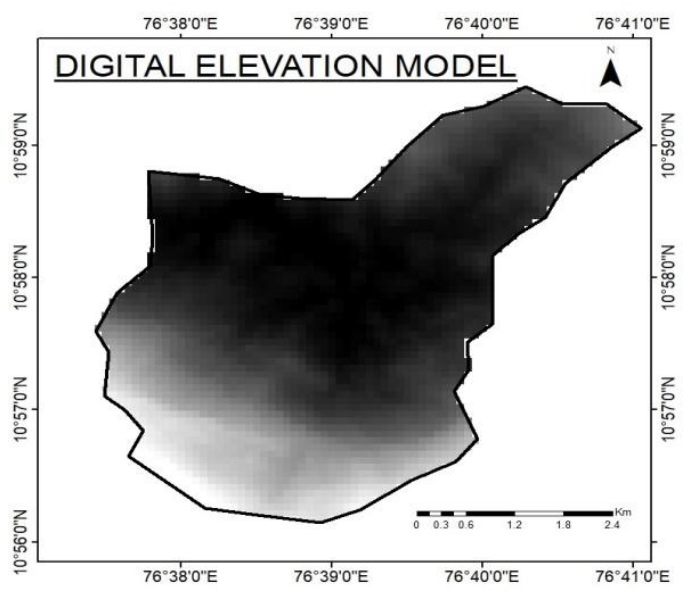

Fig.2. Digital Elevation Model

Fig. 3 and 4 shows the drainage lines of the watershed and the sub-watersheds of the siruvani reservoir.

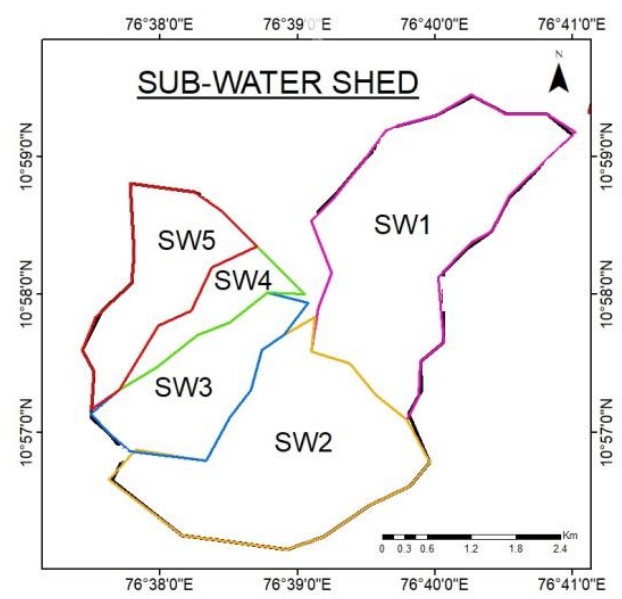

Fig.3 Sub-watersheds

\section{THE UNIVERSAL SOIL LOSS EQUATION(USLE)}

The USLE, developed by the scientists W. Wischmeier and D. Smith, has been the most widely accepted and utilized soil loss equation for over 30 years. Designed as a method to predict average annual soil loss caused by sheet and rill erosion, it can estimate long - term annual soil loss and guide conservationists on proper cropping, management, and conservation practices. The USLE is a matured technology and enhancements to it are limited by the simple equation structure.

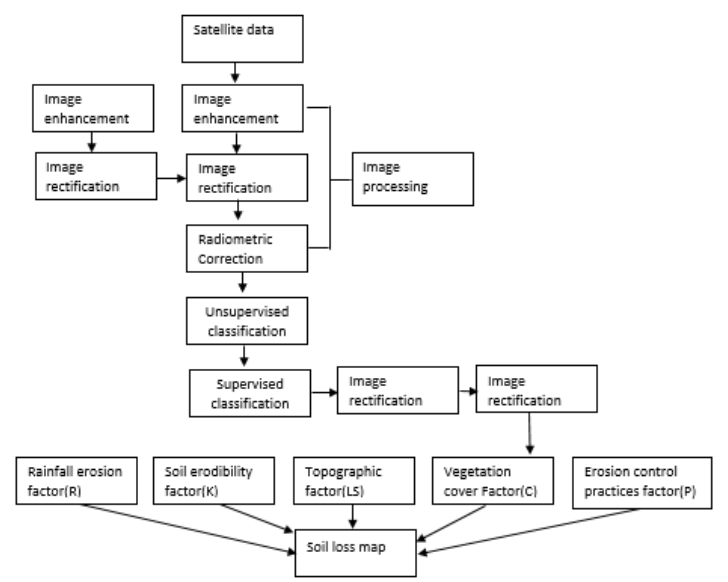

Fig.10 Methodology for Soil Loss Estimation

The USLE for estimating average annual soil erosion is: $A=R X K X L S X C X P$

- $\mathbf{A}=$ average annual soil loss in $\mathrm{t} / \mathrm{ha} / \mathrm{year}$

- $\mathbf{R}=$ rainfall erosivity index

- $\mathbf{K}=$ soil erodibility factor

- $\mathbf{L S}=$ topographic factor $-\mathrm{L}$ is for slope length $\& \mathrm{~S}$ is for slope

- $\mathbf{C}=$ cropping factor

- $\mathbf{P}=$ conservation practice factor

Evaluating the factors in USLE:

\section{$R$ - The Rainfall Erosivity Index}

Most appropriately called the erosivity index, it is a statistical parameter calculated from the annual summation of rainfall energy in every storm.

\section{$K$ - The Soil Erodibility Factor}

This factor quantifies the cohesiveness or the bonding character of a soil type and its resistance to dislodging and transport due to raindrop impact and overland flow.

\section{LS - The Topographic Factor}

Steeper slopes produce higher overland flow velocities. Longer slopes accumulate runoff from larger areas and also result in higher flow velocities. Thus, both result in increased erosion potential, but in a non - linear manner. For convenience, $\mathrm{L}$ and $\mathrm{S}$ are frequently grouped into a single term. 


\section{C - The Crop Management Factor}

This factor is the ratio of soil loss from land cropped under specified conditions corresponding to loss under tilled, continuous fallow conditions. The most computationally complicated factor of USLE factors is this factor. This factor incorporates effects of tillage, crops, seasonal erosivity index distribution, crop rotation, and crop yield level.

\section{$P$ - The Conservation Practice Factor}

This factor includes the following factors such as contouring, strip cropping and cropping practices such as terracing.

\section{RESULTS AND DISCUSSIONS}

\section{TABLE:4 ANNUAL SOIL LOSS FOR 2017 IN} TONE/HA/YEAR

\begin{tabular}{|l|l|l|l|l|l|}
\hline & SW1 & SW2 & SW3 & SW4 & SW5 \\
\hline JAN & 11000 & 10931 & 8322 & 1956 & 11418 \\
\hline FEB & 11523 & 10353 & 8283 & 1947 & 11345 \\
\hline MAR & 11449 & 10948 & 8333 & 2169 & 11952 \\
\hline APR & 10912 & 11281 & 8252 & 2150 & 10423 \\
\hline MAY & 11437 & 11949 & 8652 & 2255 & 11883 \\
\hline JUN & 11273 & 10810 & 8627 & 2255 & 11883 \\
\hline JUL & 10397 & 10831 & 8627 & 1935 & 11699 \\
\hline AUG & 10904 & 10291 & 8230 & 1935 & 11346 \\
\hline SEP & 10956 & 10889 & 8284 & 2159 & 10366 \\
\hline OCT & 10938 & 10873 & 8276 & 1705 & 11367 \\
\hline NOV & 10959 & 10895 & 8292 & 2159 & 11390 \\
\hline DEC & 10429 & 11453 & 8284 & 1706 & 11880 \\
\hline ANNUAL & 10964 & 10886 & 8708 & 2045 & 11937 \\
\hline
\end{tabular}

The TABLE:4 show the Annual soil loss for the year 2017 and its each months in tonnes/ha/year.

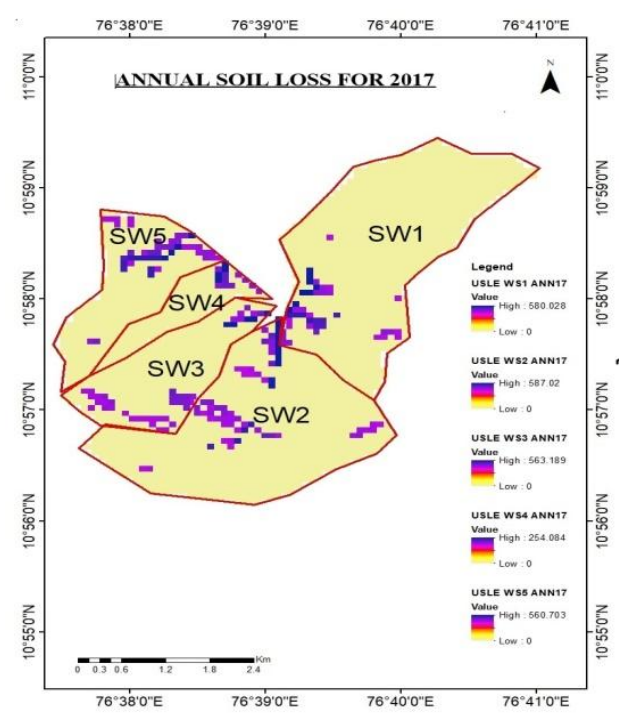

Fig.11 Soil Loss Map

\section{HYPSOMETRIC CURVE}

The hypsometric curve gives details about the formation of the basin during a period, which helps in understanding the erosion pattern in the basin. Studies reveal that the hypsometric curve and hypsometric integral are important indicators of the health of the watershed and need to be estimated for the watersheds of fragile ecosystem regions. The hypsometric integral values calculated for the subwatersheds are given in the Table. 5 .

\section{TABLE:5 HYPSOMETRIC INTEGRAL VALUE}

\begin{tabular}{|l|l|}
\hline Sl. No. & $\begin{array}{l}\text { Hypsometric Integral values } \\
\text { (Hsi) }\end{array}$ \\
\hline SW1 & 0.259 \\
\hline SW2 & 0.485 \\
\hline SW3 & 0.434 \\
\hline SW4 & 0.192 \\
\hline SW5 & 0.272 \\
\hline
\end{tabular}

It is observed from Table 5. The hypsometric integral value ranges from $0.192-0.485$ for the sub-watersheds of Siruvani reservoir. The His values of Sub-watershed2 (0.48) and aub-watershed $3(0.43)$ indicates that 48 percent and 43 percent of the original rock masses still exist in these watersheds, respectively.

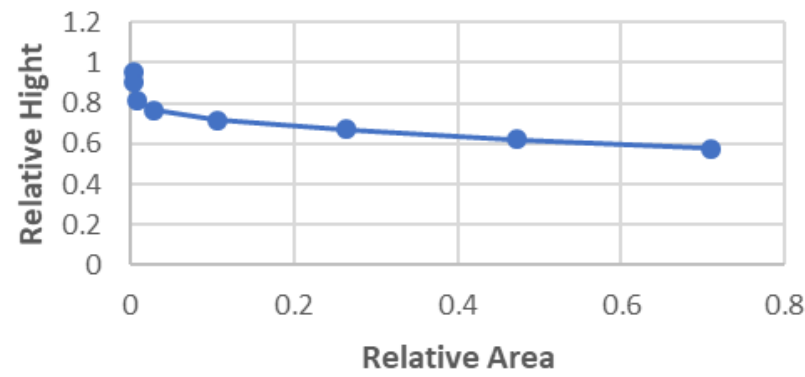

Fig.5 Hypsometric Curve for Sub-Watershed1

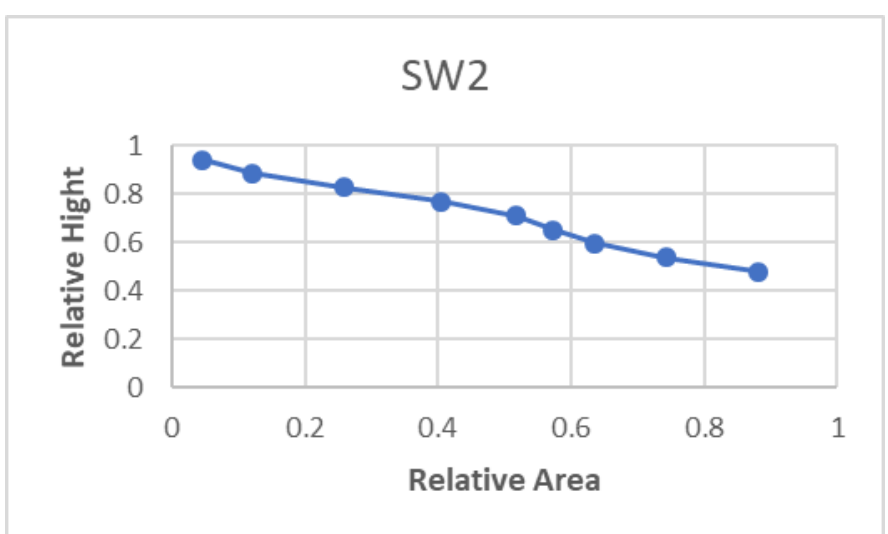

Fig.6 Hypsometric Curve for Sub-Watershed2

The hypsometric curves for the sub-watersheds of the entire Siruvani Reservoir are shown in the Figs. 5, 6, 7, 8 and 9. It is observed that there is a combination of convex and concave shape of curves, representing different stage of the basin.From the Figs. 5,6,7,8,9, it is observed that the subwatersheds 1, 4 and 5 belongs to the Monadnock phase and subwatersheds 2 and 3 belongs to the mature stage. 


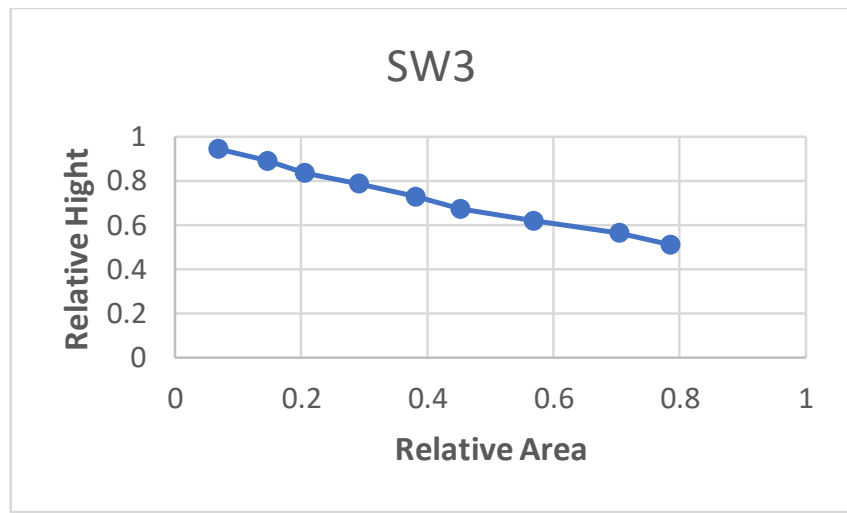

Fig.7 Hypsometric Curve for Sub-Watershed3

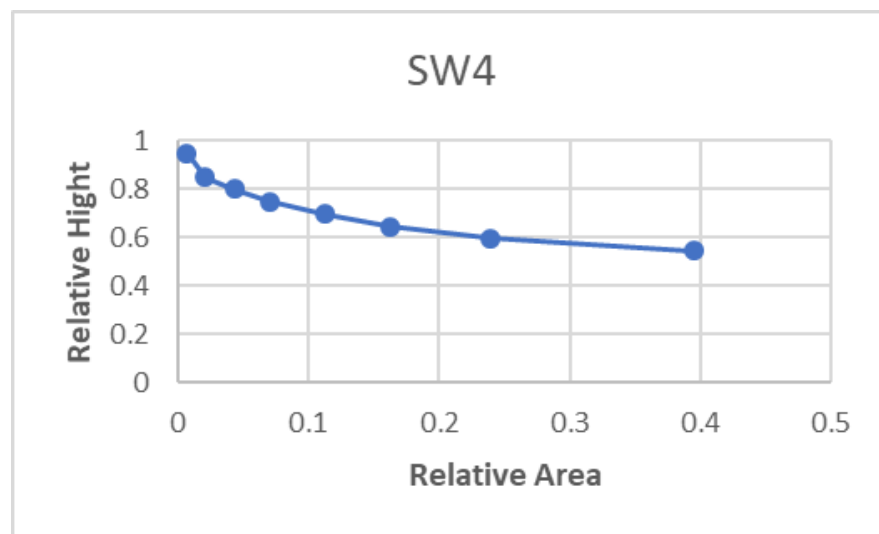

Fig.8 Hypsometric Curve for Sub-Watershed4

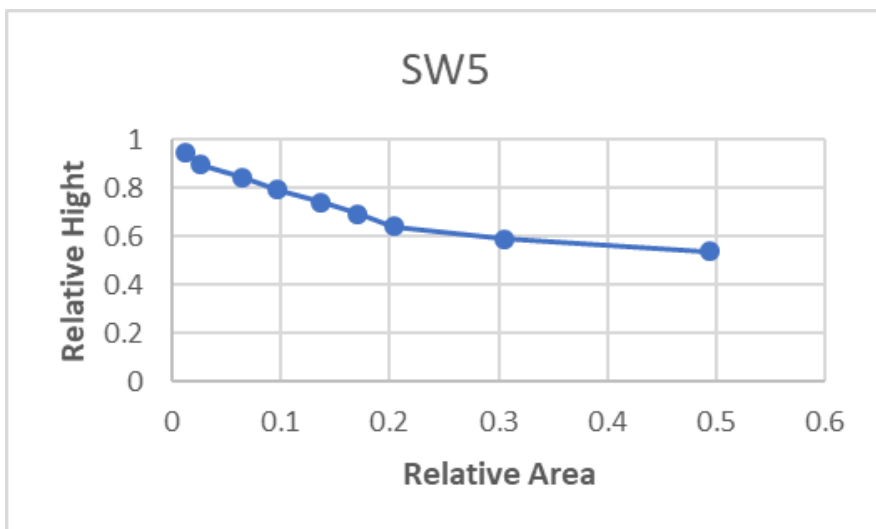

Fig.9 Hypsometric Curve for Sub-Watershed5

\section{CONCLUSIONS:}

Hypsometric analysis of the watersheds expresses the complex nature of processes in the formation of basins and the morphologicalchanges. Therefore, it is needed to conduct such studies to understand the erosion status of watersheds and prioritize them for carrying out soil and water conservation measures. The results of hypsometric integral revealed that the Subwatersheds 2 and 3 are more prone to erosion, which necessitates construction of soil and water conservation structures at appropriate locations of the watershed to arrest the sediment outflows and conserve water. The watersheds with the Hsi values less than 0.5 (i.e.approaching monadnockstage) needs minimum mechanical and vegetative measures to arrest sediment loss and augmentative structures for recharging to adapt conjunctive water use

\section{REFERENCES}

1. Fistikoglu, Okan, and Nilgun B. Harmancioglu. "Integration of GIS with USLE in assessment of soil erosion." Water Resources Management 16.6 (2002): 447-467.

2. Dabral, P. P., Neelakshi Baithuri, and Ashish Pandey. "Soil erosion assessment in a hilly catchment of North Eastern India using USLE, GIS and remote sensing." Water Resources Management 22.12 (2008): 1783-1798.

3. Pandey, Ashish, V. M. Chowdary, and B. C. Mal. "Identification of critical erosion prone areas in the small agricultural watershed using USLE, GIS and remote sensing." Water resources management 21.4 (2007): 729-746.

4. Ma, J. W., et al. "A data fusion approach for soil erosion monitoring in the Upper Yangtze River Basin of China based on Universal Soil Loss Equation (USLE) model." International Journal of Remote Sensing 24.23 (2003): 4777-4789.

5. Brema, J., and Julia Hauzinger. "Estimation of the Soil Erosion in Cauvery Watershed (Tamil Nadu and Karnataka) using USLE" International Journal of Envrionmental Science, Toxicology and Food Technology, Vol. 10 (12) (2016): 1 11.

6. Kouli, Maria, Pantelis Soupios, and Filippos Vallianatos. "Soil erosion prediction using the revised universal soil loss equation (RUSLE) in a GIS framework, Chania, Northwestern Crete, Greece." Environmental Geology 57.3 (2009): 483-497.

7. Abdo, Hazem, and Juliet Salloum. "Mapping the soil loss in Marqya basin: Syria using RUSLE model in GIS and RS techniques." Environmental Earth Sciences 76.3 (2017): 114.

8. Cohen, Sagy, Garry Willgoose, and Greg Hancock. "A methodology for calculating the spatial distribution of the area-slope equation and the hypsometric integral within a catchment." Journal of Geophysical Research: Earth Surface113.F3 (2008).

9. Khadri, S. F. R., and Nitin R. Kokate. "Hypsometric Analysis of the Morna River basin, Akola District, Maharashtra, India." International Journal on Recent and Innovation Trends in Computing and Communication 3.2 (2015): 87-92.

10. Ahmed, Fuzal, and S. K. Rao. "Hypsometric analysis of the Tuirini drainage basin: A Geographic Information System approach." International Journal of Geomatics and Geosciences 6.3 (2016): 1685-1695.

11. Luo, Wei, and John M. Harlin. "A THEORETICAL TRAVEL TIME BASED ON WATERSHED HYPSOMETRY 1." JAWRA Journal of the American Water Resources Association 39.4 (2003): 785-792.

12. Ohmori, Hiroo. "Changes in the hypsometric curve through mountain building resulting from concurrent tectonics and denudation." Geomorphology 8.4 (1993): 263-277.

13. Sudhir Kumar Singh,Vimla Singh [2016], Hypsometric Analysis Using Microwave Satellite Data and GIS of NainaGorma River Basin (Rewa district, Madhya Pradesh, India), Water Conservation Science and Engineering.

14. J.V. Pe' rez-Peña [2009], CalHypso: An ArcGIS extension to calculate hypsometric curves and their statistical moments. Applications to drainage basin analysis in Spain, Computers \& Geosciences $35: 1214-1223$ 